GENDER AND GENRE IN THE

FOLKLORE OF MIDDLE INDIA 
A volume in the series

MYTH AND POETICS

edited by Gregory NAGY

A list of thes appears at the end of the book. 


\section{GENDER AND GENRE IN THE FOLKLORE OF MIDDLE INDIA}

Joyce Burkhalter Flueckiger

CORNELL UNIVERSITY PRESS

ITHACA AND LONDON 
Open access edition funded by the National Endowment for the Humanities/ Andrew W. Mellon Foundation Humanities Open Book Program.

Cornell University Press gratefully acknowledges a grant from Emory University that aided in the publication of this book.

\section{Copyright (C) 1996 by Cornell University}

All rights reserved. Except for brief quotations in a review, this book, or parts thereof, must not be reproduced in any form without permission in writing from the publisher. For information, address Cornell University Press, Sage House, 512 East State Street, Ithaca, New York 14850, or visit our website at cornellpress.cornell.edu.

First published 1996 by Cornell University Press

Library of Congress Cataloging-in-Publication Data

Flueckiger, Joyce Burkhalter.

Gender and genre in the folklore of Middle India / Joyce Burkhalter Flueckiger.

p. cm. - (Myth and poetics)

Includes bibliographical references (p. ) and index.

ISBN-13: 978-0-8014-3206-4 (cloth) - ISBN-13: 978-0-8014-8344-8 (pbk.)

1. Folklore - India - Chattīsgaṛh (India). 2. Women - India - Chattīsgarh-

Folklore. 3. Folklore-Performance. 4. Chattīsgarh (India)-Social life and customs. I. Title. II. Series.

GR305.5.C46F58 1996

$398^{\prime} .0954^{\prime} 3$ - dc20 95-50444

The text of this book is licensed under a Creative Commons Attribution-NonCommercial-NoDerivatives 4.0 International License: https://creativecommons.org/licenses/by-nc-nd/4.0/

Cover photograph of a village festival taken by Joyce Burkhalter Flueckiger. 
with thanks to

$m y$ parents, Edward and Ramoth Burkhalter,

and the performers and audiences of Chhattisgarh 
